\section{More insults fly but Japan's 'scientific' whaling goes on}

Tokyo

THE week-long Antarctic duel between the Japanese whaling fleet and the Greenpeace ship Gondwana has left Japanese government officials furious. "Terrorism on the high seas" is how one Ministry of Agriculture, Forestry and Fisheries official angrily labelled Greenpeace's actions after the ice-strengthened Gondwana collided with the Japanese factory ship Nisshin Maru No 3 last Tuesday.

Japan's Foreign Ministry has taken a less abrasive line, saying that "terrorism is not yet the legitimate wording" for Greenpeace's attempts to halt the killing of minke whales by sending in rubber dinghies between the catcher boats and the whales. The Foreign Ministry has asked for help from the Netherlands where the Gondwana is registered.

The Foreign Ministry contends that, as the Japanese "research" fleet's activities are "in line with International Whaling Commission (IWC) stipulations", disruptive activities are "unjustifiable". But Greenpeace argues that by labelling its whaling activities as "research" Japan is exploiting a loophole in IWC rules.

Under pressure from the

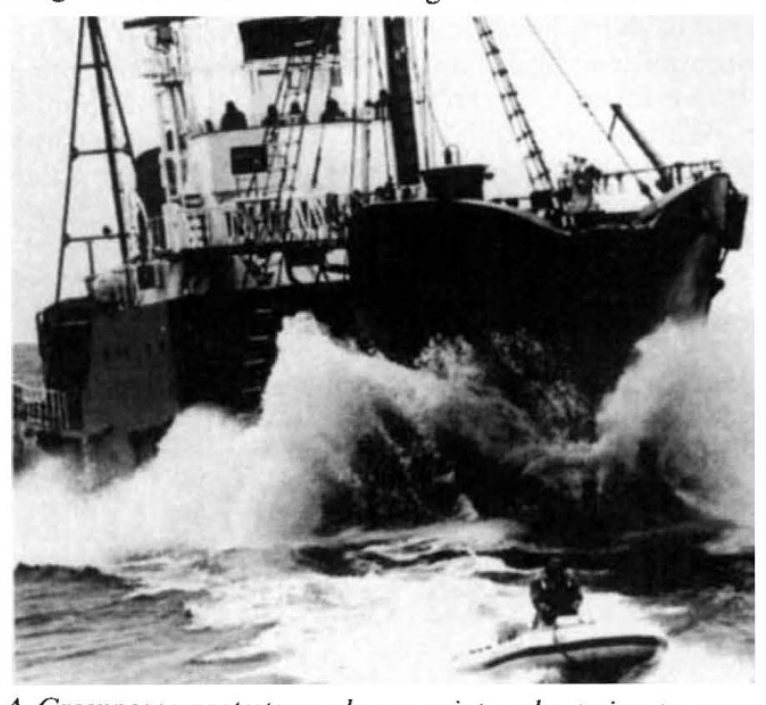

United States, Japan agreed $A$ Greenpeace protester makes a point - by trying to come to give up whaling from between whaler and whale.

1988 , in line with an IWC moratorium on commercial whaling. The moratorium was adopted because the IWC considers that the survival of some species is in doubt.

But a year before it was due to quit, Japan came up with a proposal to begin 'scientific' research whaling. Under Article 8 of the International Whaling Convention, member nations can kill as many whales as they like for scientific research purposes. Research proposals must be submitted to the IWC's scientific advisory committee but the committee's advice can be ignored.

Kazuo Yamamura, a spokesman for the Institute of Cetacean Research, responsible for managing Japan's 'scientific' whaling under government contract, argues that Japan's whaling is true scientific research. All commercial whaling companies have now closed down, he says, and the research whaling, which cost around 1,700 million yen ( $\$ 1.4$ million) in 1988 , cannot cover its costs from sale of whale meat. Substantial government grants and donations are necessary.

Although critics agree that Yamamura may be technically correct, they argue that by keeping the whaling fleet in action and restaurants stocked with whale meat, Japan's research whaling is just a way to maintain readiness for the resumption of full-scale commercial whaling operations. But Yamamura contends that Japan is obeying the commercial whaling moratorium and would begin full-scale whaling only if the IWC lifts the moratorium after the comprehensive assessement of whale stocks due for 1990 .

So far, at least, the majority of members of the IWC scientific advisory committee do not agree. Japan's original plans for scientific whaling were criticized as

unscientfic and unhelpful to the IWC goal of rationally managing whale stocks. In an unprecedented move, the IWC passed a resolution by postal ballot in February 1988 , asking Japan to stop whaling until the scientific merits of the programme could be debated. Japan ignored the ballot and continued its 'research'. But it was punished by US action that continued waters.

Since then, the first year's data have been gathered and the fleet has reached the Antarctic to begin its second season of sampling. Some 40 minke whales had been killed by the time the Gondwana, en route to supply the Greenpeace base in Antarctica, came upon the fleet in the Ross Sea. Although the harassment slowed the catch, the Fisheries Agency says the target of 300 minke whales can still be met before April.

Data amassed so far prove the success of the sampling method, according to the Fisheries Agency. But the data have yet to be independently assessed by the IWC scientific committee.

Even if scientific criticism is forthcoming, it may not shake public support Japan's zero fishing quota in US coastal

\section{Nuclear power loses popularity in Japan}

\section{Tokyo}

THE number of anti-nuclear protest meetings has reached an all-time high in Japan, according to National Police Agency figures released on Saturday, and has more than doubled since 1987.

Until the Chernobyl accident, the Japanese nuclear power industry could rely on support from the public, with the majority of citizens backing the building of more nuclear plants (see Nature 318, 595; 1985). But now surveys show supporters of nuclear construction are outnumbered two to one, with opposition particularly strong in areas near proposed construction sites.

Atomic Energy Commission officials have hit back by stressing the safety of Japan's nuclear plants and the environmental pollution caused by coal- and oilfired plants. And during the past year government and the power industry have poured extra funds into pro-nuclear publicity campaigns. But the increased strength of the opposition movement has meant bigger publicity for mishaps at nuclear plants. Last week, an announcement that a pump failure had closed the Fukushima No 2 nuclear plant quickly led to predictions that a core melt-down could have resulted if the failure had not been spotted in time.

Opposition groups are also growing more sophisticated. In Tottori prefecture, campaign groups are buying up small parcels of land at possible future plant sites to block construction. And in the northern island of Hokkaido, protesters succeeded in collecting the signature of more than two per cent of the local population at the end of last year, forcing the regional government to consider a plebiscite on the opening of a new nuclear plant.

Alun Anderson

for whaling in Japan, where the media portray the problem as largely cultural, with Japan as a misunderstood victim of Western values. Attempts to ban commercial whaling are described as "an undeniable insult to the Japanese culture and to the Japanese people" in Mainichi Daily News. In Daily Yomiuri, a Fisheries Agency official attributes "US citizens" with "special sentiments for whales"; they are equated with religious beliefs that should not be imposed on Japan.

The long-term future of Japan's offshore whaling, however, will largely depend on the IWC's comprehensive assessment of whale stocks. If the IWC rules that commercial whaling could endanger whale populations and extends the moratorium, Japan will have to decide whether to keep scientific whaling going, to abandon whaling altogether, or to pronounce the IWC as biased and leave the convention, as threatened in the past.

Alun Anderson 